liquid was then fractionally distilled: yield $88 \%$; bp $57-59{ }^{\circ} \mathrm{C}$ $(1.0 \mathrm{~mm}) ; d^{20}{ }_{4} 0.8997 ;{ }^{1} \mathrm{H} \mathrm{NMR}\left(\mathrm{CDCl}_{3}\right) \delta 0.26\left(\mathrm{~s}, 6 \mathrm{H}, \mathrm{N}-\mathrm{Si}\left(\mathrm{CH}_{3}\right)_{2}\right)$, $0.94\left(\mathrm{~s}, 9 \mathrm{H}, \mathrm{N}-\mathrm{Si}\left(\mathrm{CH}_{3}\right)_{3}\right), 2.05\left(\mathrm{~s}, 3 \mathrm{H}, \mathrm{CH}_{3} \mathrm{C}\right), 2.79\left(\mathrm{~s}, 3 \mathrm{H}, \mathrm{NCH}_{3}\right)$; mass spectrum, $m / e$ (relative intensity) $187\left(\mathrm{M}^{+}, 11\right), 127(17)$, 130 (100), $147(74), 73(66), 59$ (93). Anal. Calcd for $\mathrm{C}_{9} \mathrm{H}_{21} \mathrm{NOSi}$ C, 57.70; H, 11.30; N, 7.48; Si, 14.99. Found: C, 57.32; H, 11.12; $\mathrm{N}, 7.59 ; \mathrm{Si}, 14.96$.

$\boldsymbol{N}$-Methyl- $\boldsymbol{N}$-(tert -butyldimethylsilyl)formamide (MTBSF). Synthesis of MTBSF is the same as that for MTBSA except that $59.01 \mathrm{~g}(1.0 \mathrm{~mol})$ of $N$-methylformamide was used in place of $N$-methylacetamide: yield $93 \%$; bp $84-85^{\circ} \mathrm{C}(1.2 \mathrm{~mm})$; mp $32{ }^{\circ} \mathrm{C}$ (moist solid); ${ }^{1} \mathrm{H}$ NMR $\left(\mathrm{CDCl}_{3}\right) \delta 0.29$ (s, $6 \mathrm{H}, \mathrm{N}-\mathrm{Si}$ $\left.\left(\mathrm{CH}_{3}\right)_{2}\right), 0.93\left(\mathrm{~s}, 9 \mathrm{H}, \mathrm{SiC}\left(\mathrm{CH}_{3}\right)_{3}\right), 2.76\left(\mathrm{~s}, 3 \mathrm{H}, \mathrm{NCH}_{3}\right), 8.27(\mathrm{~s}, 1$ $\mathrm{H}, \mathrm{HC}$ ); mass spectrum, $m / e$ (relative intensity) $173\left(\mathrm{M}^{+}, 18\right)$, $158(22), 147(67), 116(100), 59(86)$. Anal. Calcd for $\mathrm{C}_{8} \mathrm{H}_{19} \mathrm{NOSi}$ : C, 55.44; H, 11.05; N, 8.08; Si, 16.20. Found: C, 55.63; H, 10.88; $\mathrm{N}, 8.19 ; \mathrm{Si}, 15.99$.

$\boldsymbol{N}, \boldsymbol{O}$-Bis (tert-butyldimethylsilyl)acetamide (BMTBSA). Synthesis of BMTBSA is the same as for MTBSA except that $29.5 \mathrm{~g}(0.5 \mathrm{~mol})$ of acetamide was used in place of $N$-methylacetamide: yield $88.7 \%$; bp $91-92{ }^{\circ} \mathrm{C}(2.0 \mathrm{~mm}) ; d^{20}{ }_{4} 0.859 ;{ }^{1} \mathrm{H}$ NMR $\left(\mathrm{CDCl}_{3}\right) \delta 0.06\left(\mathrm{~s}, 6 \mathrm{H}, O-\mathrm{Si}\left(\mathrm{CH}_{3}\right)_{2}\right), 0.22\left(\mathrm{~s}, 6 \mathrm{H}, N-\mathrm{Si}\left(\mathrm{CH}_{3}\right)_{2}\right)$, $0.87\left(\mathrm{~s}, 18 \mathrm{H}, 2 \mathrm{SiC}\left(\mathrm{CH}_{3}\right)_{3}\right), 1.93\left(\mathrm{~s}, 3 \mathrm{H}, \mathrm{CH}_{3} \mathrm{C}\right)$; mass spectrum, $m / e$ (relative intensity) $287\left(\mathrm{M}^{+}, 15\right), 272(13), 230(100), 189(33)$, 155 (78), 147 (74), 116 (22). Anal. Calcd for $\mathrm{C}_{14} \mathrm{H}_{33} \mathrm{NOSi}_{2}$ : C, 58.47; H, 11.57; N, 4.87; Si, 19.53. Found: C, 58.28; H, 11.52; N, 4.81; $\mathrm{Si}, 19.44$.

tert-Butyldimethylsilylation. All derivatizations were performed under dry nitrogen in Teflon-faced septum-capped reaction vials and flasks. Prior to silylation the organic compounds, if solid, were dissolved in a minimal amount of either dry acetonitrile or tetrahydrofuran or, if liquid, were mixed with an equal volume of acetonitrile. In all experiments performed $0.1 \mu \mathrm{M}, 1.0 \mathrm{mM}$, and $50 \mathrm{mM}$ concentrations of each compound were used. tert-Butyldimethylsilylation was accomplished by adding, via a gas-tight syringe, 10.0 equiv (based on the number of silylatable functions), of one of the following reagents: (A) MTBSTFA + 1\% TBDMSCl, (B) MTBSA + 1\% TBDMSCl, (C) $1.0 \mathrm{~m}$ TBDMSCl $+2.0 \mathrm{M}$ imidazole in DMF. tert-Butyldimethylsilylation with reagents $A$ and $B$ were allowed to proceed at room temperature for $5 \mathrm{~min}$ and for 20 minutes. Reaction mixtures with reagent $C$ were heated at $40^{\circ} \mathrm{C}$, with the progress of the reaction being determined by gas-liquid chromatography every $30 \mathrm{~min}$ for $10 \mathrm{~h}$.

Isolation of compounds following tert-butyldimethylsilylation with reagent $A$ was accomplished by removal of the acetonitrile or tetrahydrofuran in vacuo followed by the concomitant sublimation at $35{ }^{\circ} \mathrm{C}$ (15 torr) of the MTBSTFA, $N$-methyltrifluoroacetamide, and TBDMSCl from the mixture. The remaining clear residues ( $\geq 97 \%$ purity by GLC) were then sublimed or distilled. Compounds tert-butyldimethylsilylated with reagent $B$ were sublimed immediately following the removal of the reaction solvent. Compounds tert-butyldimethylsilylated with reagent $\mathrm{C}$ were generally isolated by adding the final reaction mixture to one volume of benzene or hexane and washing the mixture several times with water. The organic layer was then reduced in volume in vacuo, and the contaminating tert-butyldimethylsilanol was removed by sublimation at $35^{\circ} \mathrm{C}$ ( 15 torr). Due to the presence of DMF in reagent $C$, sublimation or distillation of the silylated product from the initial reaction was impossible.

Registry No. MTBSTFA, 77377-52-7; MTBSA, 82112-20-7; MTBSF, 68944-33-2; MtBSA, 82112-21-8; $\mathrm{RO}\left(\mathrm{CH}_{2}\right)_{3} \mathrm{OR}(\mathrm{R}=$ tertbutyldimethylsilyl), 82112-22-9; $\mathrm{ROCH}_{2} \mathrm{CH}(\mathrm{OR}) \mathrm{CH}_{2} \mathrm{OR}(\mathrm{R}=$ tertbutyldimethylsilyl), 82112-23-0; $\mathrm{C}_{6} \mathrm{HsOR}_{8}(\mathrm{R}=$ tert-butyldimethylsilyl), 18052-27-2; $\mathrm{CH}_{3} \mathrm{CH}_{2} \mathrm{CH}_{2} \mathrm{SR}$ ( $\mathrm{R}=$ tert-butyldimethylsilyl), 82112-24-1; $\left(\mathrm{CH}_{3}\right)_{2} \mathrm{CHSR}(\mathrm{R}=$ tert-butyldimethylsilyl), 82112-25-2; $\mathrm{RS}\left(\mathrm{CH}_{2}\right)_{3} \mathrm{SR}\left(\mathrm{R}=\right.$ tert-butyldimethylsilyl), 82112-26-3; $\mathrm{RSCH}_{2} \mathrm{CH}-$ (OR) $\mathrm{CH}_{2} \mathrm{OR}(\mathrm{R}=$ tert-butyldimethylsilyl), 82112-27-4; $\mathrm{RSCH}_{2} \mathrm{CH}_{2} \mathrm{OR}(\mathrm{R}=$ tert-butyldimethylsilyl), 82112-28-5; $\mathrm{RSCH}_{2} \mathrm{COOR}(\mathrm{R}=$ tert-butyldimethylsilyl), 82112-29-6; $\mathrm{ROCH}_{2} \mathrm{CH}_{2} \mathrm{COOR}$ ( $\mathrm{R}=$ tert -butyldimethylsilyl), 82112-30-9; RO-m$\mathrm{C}_{6} \mathrm{H}_{4} \mathrm{COOR}(\mathrm{R}=$ tert-butyldimethylsilyl $), 67226-77-1 ; \mathrm{RO}-0-$ $\mathrm{C}_{6} \mathrm{H}_{4} \mathrm{CH}_{2} \mathrm{OR}(\mathrm{R}=$ tert-butyldimethylsilyl), 82112-31-0; RO-p$\mathrm{C}_{6} \mathrm{H}_{4} \mathrm{CH}_{2} \mathrm{COCOOR}$ ( $\mathrm{R}=$ tert-butyldimethylsilyl), 82112-32-1; DL$\mathrm{C}_{2} \mathrm{HsCH}(\mathrm{NHR}) \mathrm{COOR}(\mathrm{R}=$ tert-butyldimethylsilyl), 82112-33-2; $\mathrm{C}_{2} \mathrm{HsCH}(\mathrm{NHR}) \mathrm{CH}_{2} \mathrm{OR}(\mathrm{R}=$ tert-butyldimethylsilyl), 82112-34-3;
$\mathrm{CH}_{3} \mathrm{CH}$ (NHR) $\mathrm{CH}_{2} \mathrm{OR}$ ( $\mathrm{R}=$ tert-butyldimethylsilyl), 82134-49-4; 2,4-(OR)-6-(RNH)pyrimidine ( $\mathrm{R}=$ tert-butyldimethylsilyl), 8211235-4; $\mathrm{C}_{8} \mathrm{HsCH}_{2} \mathrm{NR}\left(\mathrm{CH}_{3}\right)$ ( $\mathrm{R}=$ tert-butyldimethylsilyl), 82112-36-5; 1,3-propanediol, 504-63-2; glycerol, 56-81-5; phenol, 108-95-2; 1 propanethiol, 107-03-9; 2-propanethiol, 75-33-2; 1,3-propanedithiol, 109-80-8; 2-mercapto-1,2-propanediol, 96-27-5; 2-mercaptoethanol, 60-24-2; mercaptoacetic acid, 68-11-1; 3-hydroxypropionic acid, 503-66-2; $m$-hydroxybenzoic acid, 99-06-9; 2-hydroxybenzyl alcohol, 90-01-7; $p$-hydroxyphenylpyruvic acid, 156-39-8; DL-2-aminobutyric acid, 2835-81-6; 2-amino-1-butanol, 96-20-8; 2-amino-1-propanol, 78-91-1; 4-amino-2,6-dihydroxypyrimidine, 873-83-6; benzylmethylamine, 103-67-3; tert-butyldimethylsilyl chloride, 18162-48-6; $N$ methyltrifluoroacetamide, 815-06-5; $N$-methylacetamide, 79-16-3; $N$-methylformamide, 123-39-7; acetamide, 60-35-5.

\section{Reactions of Enamines with Trifluoroacetic Anhydride: Trifluoroacetylation and the Formation of 1,3-Oxazines}

Willem Verboom and David N. Reinhoudt*

\section{Laboratory of Organic Chemistry, Twente University of Technology, Enschede, The Netherlands}

Sybolt Harkema and Gerrit J. van Hummel

Laboratory of Chemical Physics, Twente University of Technology, Enschede, The Netherlands

\section{Received February 23, 1982}

In relation to our work on the synthesis of analogues of the antitumor antibiotic mitomycin $\mathrm{C}$, we are currently interested in the reactions of pyrrolizines, prepared by reaction of 1-(1-pyrrolidinyl)cycloalkenes and dimethyl acetylenedicarboxylate (DMAD), with trifluoroacetic anhydride (TFA). Kametani et al. used this reagent for the conversion of pyrroloindoles into azocines. ${ }^{1}$ Recently, we have reported that one of the pyrroloindoles that we have synthesized, viz., methyl 7a,8,9,10-tetrahydro-7-(methoxycarbonyl)-7 $H$-benzo[g]pyrrolo[1,2-a]indole-7-acetate, reacted in a different way with TFA, namely, via trifluoroacetylation of the aromatic ring. ${ }^{2}$ This result led us to investigate reactions of other pyrrolizines with TFA.

We found that methyl $1,2,3,5,6,7,7 a, 8$-octahydro-8(methoxycarbonyl)cyclopenta[b]pyrrolizine-8-acetate (1, $\left.\mathrm{E}=\mathrm{COOCH}_{3}\right)^{3}$ reacted smoothly with TFA at room temperature to give one product in $65 \%$ yield. According to the mass spectrum and elemental analysis, the elemental composition of the reaction product was $\mathrm{C}_{17} \mathrm{H}_{20} \mathrm{~F}_{3} \mathrm{NO}_{5}$, indicating that trifluoroacetylation had taken place.

In the ${ }^{1} \mathrm{H}$ NMR spectrum, the characteristic $\mathrm{NCH}$ absorption at $\delta 4.74$ (dd, $J=5$ and $12 \mathrm{~Hz}$ ) was still present. $\mathrm{X}$-ray diffraction showed that the compound had the methyl 1,2,5,6,7,7a,8,8a-octahydro-8-(methoxycarbonyl)3 -(trifluoroacetyl)cyclopenta[b] pyrrolizine-8-acetate (3) structure (Figure 1). We assume that this reaction of 1 proceeds via its tautomeric form 2 (Scheme I) in which trifluoroacetylation takes place at the $\beta$-enamine carbon atom.

The surprising result of the reaction of 1 , which possesses an enamine moiety, with TFA led us to study the reaction of other enamines with this reagent. To our knowledge such reactions have not been reported in the literature, although reactions with acetic anhydride ${ }^{4,5}$ and

(1) Kametani, T.; Takahashi, K.; Ihara, M.; Fukumoto, K. J. Chem. Soc., Perkin Trans. 1 1979, 1847.

(2) Verboom, W.; Visser, G. W.; Reinhoudt, D. N. Tetrahedron, 1982, 38,1831 .

(3) Verboom, W.; Visser, G. W.; Trompenaars, W. P.; Reinhoudt, D. N.; Harkema, S.; van Hummel, G. J. Tetrahedron 1981, 37, 3525. 


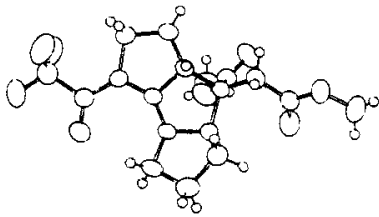

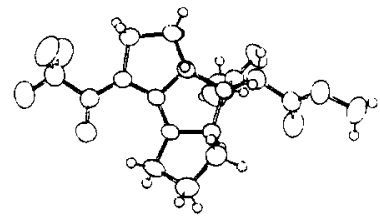

Figure 1. Stereoscopic view of compound 3.

Scheme I

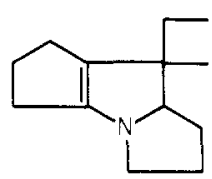

1
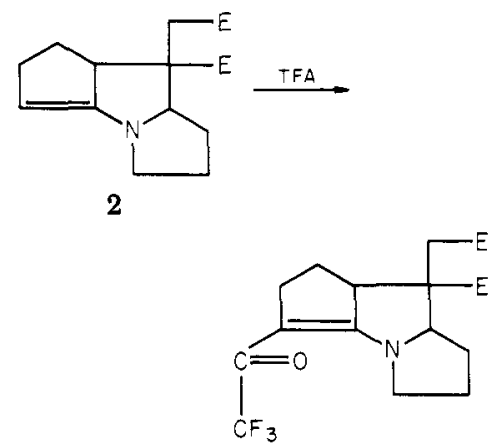

3

Scheme II

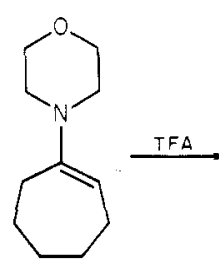

4

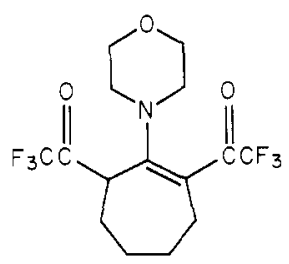

5 with trichloroacetic anhydride ${ }^{6}$ are known.

Reaction of 4-(1-cyclohepten-1-yl)morpholine (4) with 2.5 equiv of TFA in tetrahydrofuran (THF) at room temperature afforded the 4-[2,7-bis(trifluoroacetyl)-1-cyclohepten-1-yl]morpholine (5), which after distillation was isolated in $57 \%$ yield (Scheme II). The mass spectrum and elemental analysis showed that two $\mathrm{CF}_{3} \mathrm{CO}$ groups had been introduced.

More reactive enamines, such as 4-(1-cyclopenten-1yl)morpholine and 1-(1-cyclohexen-1-yl)pyrrolidine, reacted even at low temperature, to give very complicated reaction mixtures. It has been reported that these types of enamines react with an excess of acetic anhydride to produce only monoacetylation. ${ }^{4}$

4-(3,4-Dihydro-1-naphthalenyl)morpholine (6a) and 1-(1H-inden-3-yl)pyrrolidine $(6 \mathbf{b})$ reacted with TFA in THF to give, after distillation, the trifluoroacetylated compounds $7 \mathbf{a}, \mathbf{b}$ in yields of 83 and $82 \%$, respectively (Scheme III). Isolation of $\mathbf{7 a}, \mathbf{b}$ by column chromatography of the crude reaction mixture on silica gel or alumina was not possible because of decomposition.

Reaction of 1-(3,4-dihydro-1-naphthalenyl)pyrrolidine (6c) with TFA in THF, however, afforded, after distillation, a mixture of products, of which the minor compound was the trifluoroacetylated compound $\mathbf{7 c}$. After column chromatography (alumina), the major reaction product, a white crystalline compound, was isolated in a yield of $53 \%$. Mass spectrometry and elemental analysis exhibited that a $\mathrm{CF}_{3} \mathrm{CO}$ moiety had been introduced, but the absence of a carbonyl group (IR and ${ }^{13} \mathrm{C}$ NMR spectroscopy) ruled

(4) Cook, A. G., Ed. "Enamines: Synthesis, Structure and Reactions"; Marcel Dekker: New York, 1969.

(5) Weber, J.; Faller, P. C. R. Hebd. Seances Acad. Sci., Ser. C 1975, 281,389 .

(6) Morimoto, T.; Sekiya, M. Chem. Pharm. Bull. 1978, 26, 1586.
Scheme III<smiles>[X]CCN(C)C(=C)c1ccccc1[Y]</smiles>

6

$\mathrm{a}, \mathrm{X}=\mathrm{O} ; \mathrm{Y}=\mathrm{CH}_{2}$

b, $\mathrm{X}=-; \mathrm{Y}=-$

c, $\mathrm{X}=-; \mathrm{Y}=\mathrm{CH}_{2}$

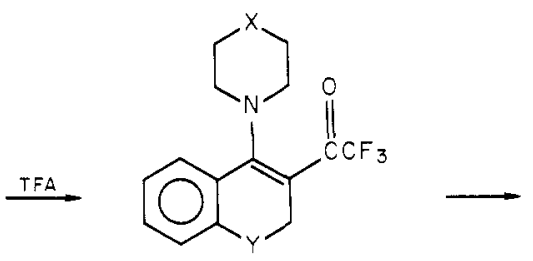

$$
\text { d, } \mathrm{X}=\mathrm{CH}_{2} ; \mathrm{Y}=\mathrm{CH}_{2}
$$$$
\text { e, } \mathrm{X}=-; \mathrm{Y}=\mathrm{CH}_{2} \mathrm{CH}_{2}
$$

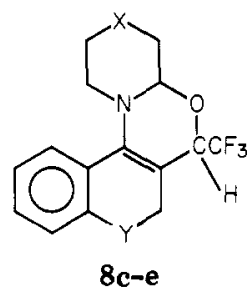

Scheme IV

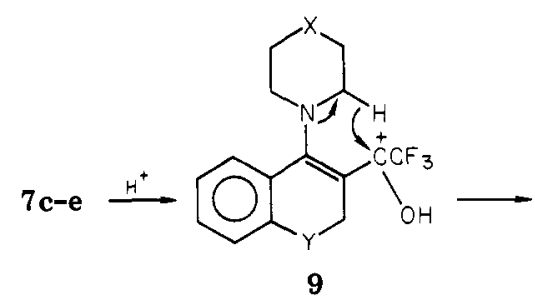

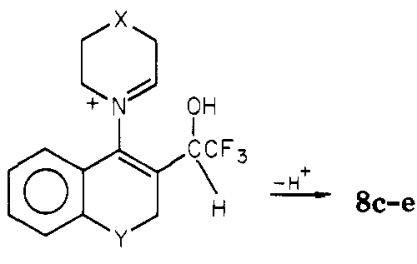

10

out a structure like 7c. The ${ }^{1} \mathrm{H}$ NMR spectrum showed characteristic absorptions at $\delta 5.05(\mathrm{br} \mathrm{d}, J=4.2 \mathrm{~Hz}, 1 \mathrm{H}$ ) and $4.54\left(\mathrm{q}, J=7.8 \mathrm{~Hz}, 1 \mathrm{H}\right.$ ), and the ${ }^{13} \mathrm{C}$ NMR spectrum showed characteristic absorptions at $\delta 86.5$ (d) and 72.8 (dq, $J=29.6 \mathrm{~Hz}$ ). On the basis of these and other spectroscopic data, we concluded that the reaction product was 1,2,3,3a,6,7-hexahydro-5-(trifluoromethyl)- $5 \mathrm{H}$-naphtho[1,2-d]pyrrolo[2,1-b][1,3]oxazine (8c). TLC of the crude reaction mixture revealed that $6 \mathrm{c}$ had reacted possibly to 7c. However, 8c was not present, so that further reaction must have occurred during the distillation.

1-(3,4-Dihydro-1-naphthalenyl)piperidine (6d) reacted similarly to give, after distillation, the $2,3,4,4 \mathrm{a}, 7,8$-hexahydro-6-(trifluoromethyl)- $1 \mathrm{H}, 6 \mathrm{H}$-naphtho[1,2-d]pyrido$[2,1-b][1,3]$ oxazine (8d) in $44 \%$ yield as a mixture of two isomers.

Reaction of 1-(6,7-dihydro-5H-benzocyclohepten-9-yl)pyrrolidine (6e) with TFA afforded, after distillation, 7e, slightly contaminated with the 1,3-oxazine 8e in a yield of $87 \%$. Compound $7 \mathrm{e}$ could not be isolated in a pure state on account of decomposition on silica gel and alumina. Heating of $7 \mathbf{e}$ in toluene in the presence of trifluoroacetic acid for 3 days yielded, after column chromatography, the 1,2,3,3a,5,6,7,8-octahydro-5-(trifluoromethyl) benzo[6,7]cyclohepta[1,2-d]pyrrolo $[2,1-b][1,3]$ oxazine (8e) in a yield of $30 \%$ as a mixture of isomers. This experiment demonstrated that the 1,3-oxazine formation takes place via the trifluoroacetylated compounds 7. Starting from 7, the formation of 8 can be rationalized as depicted in Scheme IV. Protonation of $7 \mathrm{c}-\mathbf{e}$ will give the stabilized carboca- 
tion 9 , in which a hydride transfer takes place to $\mathbf{1 0}$. Subsequently, intramolecular addition of the hydroxy group to the iminium double bond gives rise to compounds $8 c-e$. An intermediate such as 10 has also been proposed in order to explain the formation of dihydrobenzimidazoles by reaction of anils of ortho-substituted amines in the presence of acid as described by Meth-Cohn et al.; the conversion of 10 into $8 \mathrm{c}-\mathrm{e}$ represents the well-known reaction of alcohols with iminium salts. ${ }^{8}$

\section{Experimental Section}

Melting points were determined with a Reichert melting point apparatus and are uncorrected. ${ }^{1} \mathrm{H}$ and ${ }^{13} \mathrm{C}$ NMR spectra $\left(\mathrm{CDCl}_{8}\right)$ were recorded with a WP80-FT spectrometer $\left(\mathrm{Me}_{4} \mathrm{Si}\right.$ as internal standard). Mass spectra were obtained with a Varian Mat 311A spectrometer, and IR spectra were obtained with a Perkin-Elmer 257 spectrophotometer. Elemental analyses were carried out by the Element Analytical Section of the Institute for Organic Chemistry TNO, Utrecht, The Netherlands, under supervision of W. J. Buis. THF was distilled prior to use from sodium benzophenone ketyl. All reactions were carried out under a nitrogen atmosphere.

Methyl 1,2,5,6,7,7a,8,8a-Octahydro-8-(methoxycarbonyl)-3-(trifluoroacetyl)cyclopenta[b]pyrrolizine-8acetate (3). A suspension of $1^{3}(1.0 \mathrm{~g}, 3.6 \mathrm{mmol})$ in $10 \mathrm{~mL}$ of TFA was stirred at room temperature for $45 \mathrm{~min}$. The TFA was removed under reduced pressure, and the residue was dissolved in $25 \mathrm{~mL}$ of $\mathrm{CHCl}_{3}$. This solution was stirred for $30 \mathrm{~min}$ with $\mathrm{K}_{2} \mathrm{CO}_{3}(5 \mathrm{~g})$. After filtration, the $\mathrm{CHCl}_{3}$ was evaporated to give an oil, which after crystallization from $\mathrm{Et}_{2} \mathrm{O}$ gave $65 \%$ of $3: \mathrm{mp}$ 128-129 ${ }^{\circ} \mathrm{C}$; IR (KBr) $1730\left(\mathrm{C}=0\right.$, esters), $1665\left(\mathrm{O}=\mathrm{CCF}_{3}\right) \mathrm{cm}^{-1}$. ${ }^{1} \mathrm{H}$ NMR $\delta 4.74$ (dd, $J=5$ and $\left.12 \mathrm{~Hz}, \mathrm{NCH}\right), 4.0-3.6(\mathrm{~m}, 2 \mathrm{H}$, $\left.\mathrm{NCH}_{2}\right), 3.72$ and $3.67\left(\mathrm{~s}, \mathrm{OCH}_{3}\right), 3.25$ and $2.55(\mathrm{AB} \mathrm{q} J=18 \mathrm{~Hz}$ $\left.\mathrm{CH}_{2} \mathrm{E}\right)$, 3.3-3.1 (m, $\left.1 \mathrm{H}, \mathrm{CH}\right), 3.0-2.7\left(\mathrm{~m}, 2 \mathrm{H}, \mathrm{H}_{2} \mathrm{CC}=\right)$, 2.2-1.1 $\left(\mathrm{m}, 6 \mathrm{H}, \mathrm{CH}_{2}\right) ;{ }^{13} \mathrm{C}$ NMR $\delta 172.3$ and $171.3(\mathrm{~s}, \mathrm{C}=0), 117.5(\mathrm{q}$, $\left.J=291 \mathrm{~Hz}, \mathrm{CF}_{3}\right), 79.7(\mathrm{~d}, \mathrm{NCH}), 61.7(\mathrm{~d}, \mathrm{CH}), 52.4$ and $51.9(\mathrm{q}$, $\left.\mathrm{OCH}_{3}\right), 48.8\left(\mathrm{t}, \mathrm{NCH}_{2}\right), 47.4\left[\mathrm{~s}, \mathrm{C}(\mathrm{E}) \mathrm{CH}_{2} \mathrm{E}\right], 38.4\left(\mathrm{t}, \mathrm{CH}_{2} \mathrm{E}\right), 33.2$ 26.6, 26.2, and $25.5\left(\mathrm{t}, \mathrm{CH}_{2}\right) ;$ mass spectrum, $m / e 375.130\left(\mathrm{M}^{+}\right.$; calcd 375.129).

Anal. Calcd for $\mathrm{C}_{17} \mathrm{H}_{20} \mathrm{~F}_{3} \mathrm{NO}_{5}: \mathrm{C}, 54.40 ; \mathrm{H}, 5.37 ; \mathrm{N}, 3.73$. Found: $\mathrm{C}, 54.44 ; \mathrm{H}, 5.36 ; \mathrm{N}, 3.64$.

4-[2,7-Bis(trifluoroacetyl)-1-cyclohepten-1-yl]morpholine (5). To a stirred solution of $4^{10}(3.6 \mathrm{~g}, 20 \mathrm{mmol})$ in $15 \mathrm{~mL}$ of THF was added TFA $(10.5 \mathrm{~g}, 50 \mathrm{mmol})$, the temperature being kept between 15 and $25^{\circ} \mathrm{C}$. After $1.5 \mathrm{~h}$ of stirring, the solvent was removed under reduced pressure. Distillation of the resulting oil afforded $57 \%$ of 5 as an oil, bp $137-139^{\circ} \mathrm{C}(2 \mathrm{~mm})$, which after crystallization from $\mathrm{Et}_{2} \mathrm{O}$ gave yellow crystals: $\mathrm{mp} 167-169^{\circ} \mathrm{C}$; ${ }^{1} \mathrm{H}$ NMR $\left(\mathrm{Me}_{2} \mathrm{SO}-d_{6}\right) \delta 3.9-3.5\left(\mathrm{~m}, 4 \mathrm{H}, \mathrm{OCH}_{2}\right), 3.4-3.0(\mathrm{~m}, 4 \mathrm{H}$, $\left.\mathrm{NCH}_{2}\right), 2.9-1.2\left(\mathrm{~m}, 8 \mathrm{H}, \mathrm{CH}_{2}\right) ;{ }^{13} \mathrm{C} \mathrm{NMR}\left(\mathrm{Me}_{2} \mathrm{SO}-d_{6}\right) \delta 130.7(\mathrm{q}$, $\left.J=280 \mathrm{~Hz}_{2} \mathrm{CF}_{3}\right), 65.6\left(\mathrm{t}, \mathrm{OCH}_{2}\right), 52.1\left(\mathrm{t}, \mathrm{NCH}_{2}\right), 28.5,28.2$, and $27.4\left(\mathrm{t}, \mathrm{br}, \mathrm{CH}_{2}\right) ;$ mass spectrum, $m / e 373.114\left(\mathrm{M}^{+} ;\right.$calcd 373.111$)$.

Anal. Calcd for $\mathrm{C}_{15} \mathrm{H}_{17} \mathrm{~F}_{6} \mathrm{NO}_{3} ; \mathrm{C}, 48.26 ; \mathrm{H}, 4.59 ; \mathrm{N}, 3.75$. Found: $\mathrm{C}, 48.10 ; \mathrm{H}, 4.61 ; \mathrm{N}, 3.75$.

2,2,2-Trifluoro-3',4'-dihydro-1'-morpholino-2'-acetonaphthone (7a) and 3-(1-Pyrrolidinyl)inden-2-yl Trifluoromethyl Ketone (7b). TFA $(4.2 \mathrm{~g}, 20 \mathrm{mmol})$ was added to a solution of $6 \mathbf{a}^{11}$ and $6 \mathbf{b}^{12}(10 \mathrm{mmol})$ in $15 \mathrm{~mL}$ of THF at $15-25$ ${ }^{\circ} \mathrm{C}$, and the solution was stirred for $1 \mathrm{~h}$ at room temperature. The solvent was removed under reduced pressure. Distillation [bp $\left.139-143^{\circ} \mathrm{C}(0.5 \mathrm{~mm})\right]$ afforded $7 \mathrm{a}$ as a solid in $83 \%$ yield, and $7 \mathrm{~b}$, after trituration with isopropyl ether, as a solid in $82 \%$ yield respectively.

7a: $\mathrm{mp} 134-137^{\circ} \mathrm{C} \operatorname{dec}(\mathrm{MeOH}){ }^{1} \mathrm{H}$ NMR $\delta 7.8-7.6(\mathrm{~m}, 1 \mathrm{H}$, Ar H), 7.45-7.1 (m, $3 \mathrm{H}, \mathrm{Ar} \mathrm{H}), 4.0-3.7\left(\mathrm{~m}, 4 \mathrm{H}, \mathrm{OCH}_{2}\right), 3.15-2.8$

(7) Grantham, R. K.; Meth-Cohn, O.; Naqui, M. A. J. Chem. Soc. C 1969,1438

(8) Böhme, H.; Haake, M. Adv. Org. Chem. 1976, 9,162

(9) Winterfeldt, E. Preuss, H. Chem. Ber 1966, 99,450

(10) Stork, G.; Brizzolara, A.; Landesman, H.; Szmuszkovicz, J.; Terrel, R. J. Am. Chem. Soc. 1963, 85, 207.

(11) Vlugt, F. A. v. d.; Verhoeven, J. W.; Pandit, U. K. Recl. Trav. Chim. Pays-Bas 1970, 89, 1258

(12) Reiss, K. Ph.D. Thesis, Munich, 1978. $\left(\mathrm{m}, 4 \mathrm{H}, \mathrm{NCH}_{2}\right), 2.8-2.3\left(\mathrm{~m}, 4 \mathrm{H}, \mathrm{CH}_{2}\right) ;{ }^{13} \mathrm{C} \mathrm{NMR} \delta 159.9(\mathrm{~s}, \mathrm{NC}=)$, 142.5 (s), 130.7 (s), 130.5 (d), 128.3 (d), 127.2 (d), 126.3 (d) (Ar C), $117.0\left(\mathrm{q}, J=290 \mathrm{~Hz}, \mathrm{CF}_{3}\right) 109.9(\mathrm{~s}, \mathrm{NC}=\mathrm{C}), 66.9\left(\mathrm{t}, \mathrm{OCH}_{2}\right)$, $52.2\left(\mathrm{t}, \mathrm{NCH}_{2}\right), 29.0$ and $23.6\left(\mathrm{t}, \mathrm{CH}_{2}\right)$; mass spectrum, $m / e 311.116$ $\left(\mathrm{M}^{+}\right.$; calcd 311.113).

Anal. Calcd for $\mathrm{C}_{17} \mathrm{H}_{18} \mathrm{~F}_{3} \mathrm{NO}_{2}: \mathrm{C}, 61.73 ; \mathrm{H}, 5.18 ; \mathrm{N}, 4.50$. Found: $\mathrm{C}, 61.67 ; \mathrm{H}, 5.23 ; \mathrm{N}, 4.36$.

7b: $\mathrm{mp}{ }^{149-150}{ }^{\circ} \mathrm{C}\left(\mathrm{Et}_{2} \mathrm{O}\right) ;{ }^{1} \mathrm{H}$ NMR $\delta 8.0-7.8(\mathrm{~m}, 1 \mathrm{H}, \mathrm{Ar} \mathrm{H})$, 7.6-7.2 (m, $3 \mathrm{H}, \mathrm{Ar} \mathrm{H}), 4.0-3.7\left(\mathrm{~m}, 6 \mathrm{H}, \mathrm{NCH}_{2}\right.$ and $\left.\mathrm{CH}_{2} \mathrm{C}=\right)$, 2.3-1.9 (m, $\left.4 \mathrm{H}, \mathrm{CH}_{2}\right) ;{ }^{13} \mathrm{C}$ NMR $\delta 168.2(\mathrm{q}, J=30 \mathrm{~Hz}, \mathrm{C}=\mathrm{O})$, 162.7 (s, NC=), 145.8 (s), 137.6 (s), 129.9 (d), 126.5 (d), 125.3 (d), 124.8 (d) ( $\mathrm{Ar} \mathrm{C}$ ), 118.4 (q, $J=291 \mathrm{~Hz}, \mathrm{CF}_{3}$ ), 102.8 (s, NC=C), $54.6\left(\mathrm{t}, \mathrm{NCH}_{2}\right), 34.7\left(\mathrm{t}, \mathrm{CH}_{2} \mathrm{C}=\right), 25.8\left(\mathrm{t}, \mathrm{CH}_{2}\right)$; mass spectrum, $\mathrm{m} / \mathrm{e} 281.103\left(\mathrm{M}^{+}\right.$; calcd 281.103).

Anal. Calcd for $\mathrm{C}_{15} \mathrm{H}_{14} \mathrm{~F}_{3} \mathrm{NO}: \mathrm{C}, 64.05 ; \mathrm{H}, 5.02 ; \mathrm{N}, 4.98$. Found: C, 64.28; H, 4.94; N, 4.92.

1,2,3,3a,6,7-Hexahydro-5-(trifluoromethyl)-5 $H$-naphtho[1,2-d]pyrrolo[2,1-b][1,3]oxazine (8c) and $2,3,4,4 a, 7,8$-Hexahydro-6-(trifluoromethyl) $-1 H, 6 H$-naphtho $[1,2-d] p y r i d o-$ $[2,1-b][1,3]$ oxazine (8d). Starting from $6 c, \mathbf{d}^{11}(10 \mathrm{mmol})$, the reaction was carried out as described above. The solvent was removed under reduced pressure, and the resulting oil was distilled. The fraction with bp $139-143^{\circ} \mathrm{C}(0.5 \mathrm{~mm})$ was purified by column chromatography [alumina (V), petroleum ether (bp $60-80^{\circ} \mathrm{C}$ ) with $5 \% \mathrm{CHCl}_{3}$ ], yielding $8 \mathrm{c}$ and $8 \mathrm{~d}$ in 53 and $44 \%$ yield, respectively.

8c: $\mathrm{mp} \mathrm{85-86.5}{ }^{\circ} \mathrm{C}(\mathrm{MeOH})$; IR $(\mathrm{KBr}) 1638(\mathrm{C}=\mathrm{C}) \mathrm{cm}^{-1} ;{ }^{1} \mathrm{H}$ NMR $\delta 7.5-7.0(\mathrm{~m}, 4 \mathrm{H}, \mathrm{Ar} \mathrm{H}), 5.05$ (d, br, $J=4.2 \mathrm{~Hz}, \mathrm{NCHO}$ ), 4.54 (q, $\left.J=7.8 \mathrm{~Hz}, \mathrm{~F}_{3} \mathrm{CCH}\right), 3.7-3.35[\mathrm{~m}, 1 \mathrm{H}, \mathrm{NC}(\mathrm{H}) \mathrm{H}], 3.0-1.7$ (m, $9 \mathrm{H}$ ); ${ }^{13} \mathrm{C}$ NMR $\delta 139.6,136.6$, and 131.0 (s, NC= and $\mathrm{Ar} \mathrm{C}$ ), 127.6, 127.4, 126.3, and 123.7 (d, $\mathrm{Ar}$ C), $124.6\left(\mathrm{q}, J=288 \mathrm{~Hz}, \mathrm{CF}_{3}\right.$ ), $109.1(\mathrm{~s}, \mathrm{NC}=\mathrm{C}), 86.5$ and $86.4(\mathrm{~d}, \mathrm{NCHO}), 72.8(\mathrm{dq}, J=29.6$ $\left.\mathrm{Hz}, \mathrm{F}_{3} \mathrm{CCH}\right), 50.7\left(\mathrm{t}, \mathrm{NCH}_{2}\right), 31.9,28.0,24.1$, and $23.2\left(\mathrm{t}, \mathrm{CH}_{2}\right)$; mass spectrum, $m / e 295.119\left(\mathrm{M}^{+}\right.$; calcd 295.118).

Anal. Calcd for $\mathrm{C}_{16} \mathrm{H}_{16} \mathrm{~F}_{3} \mathrm{NO}$ : $\mathrm{C}, 65.13 ; \mathrm{H}, 5.45 ; \mathrm{N}, 4.64$. Found: C, 65.07; H, 5.46; N, 4.74 .

8d: $\mathrm{mp} 87-90^{\circ} \mathrm{C}$ dec $(\mathrm{MeOH})$; IR $(\mathrm{KBr}) 1646(\mathrm{C}=\mathrm{C}) \mathrm{cm}^{-1}$; ${ }^{1} \mathrm{H}$ NMR $\delta$ 7.6-7.0 (m, $\left.4 \mathrm{H}, \mathrm{Ar} \mathrm{H}\right), 4.9-4.5(\mathrm{~m}, 2 \mathrm{H}$, NCHO and $\left.\mathrm{F}_{3} \mathrm{CCH}\right), 3.2-1.5\left(\mathrm{~m}, 12 \mathrm{H}, \mathrm{CH}_{2}\right) ;{ }^{13} \mathrm{C} \mathrm{NMR} \delta 144.25(\mathrm{~s}, \mathrm{NC}=)$, 136.7 (s), 136.3 (s), 130.3 (s), 129.6 (s), 127.4 (d), 127.2 (d), 126.1 (d), 122.6 (d) and 122.2 (d) (Ar C), $124.3\left(\mathrm{q}, J=288 \mathrm{~Hz}, \mathrm{CF}_{3}\right.$ ), $113.5(\mathrm{~s}, \mathrm{NC}=\mathrm{C}), 82.9$ and $81.7(\mathrm{~d}, \mathrm{NCHO}), 75.0$ and $73.2(\mathrm{dq}$, $\left.J=29 \mathrm{~Hz}, \mathrm{~F}_{3} \mathrm{CCH}\right), 46.1\left(\mathrm{t}, \mathrm{NCH}_{2}\right) ;$ mass spectrum, $m / e 309.134$ $\left(\mathrm{M}^{+}\right.$; calcd 309.134).

Anal. Calcd for $\mathrm{C}_{17} \mathrm{H}_{18} \mathrm{~F}_{3} \mathrm{NO}$ : $\mathrm{C}, 66.01 ; \mathrm{H}, 5.87 ; \mathrm{N}, 4.53$. Found: C, $66.02 ; \mathrm{H}, 5.90 ; \mathrm{N}, 4.41$.

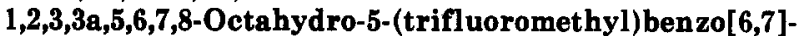
cyclohepta[ $[1,2-d][1,3]$ oxazine (8e). Reaction of $6 \mathrm{e}^{13}(2.1 \mathrm{~g}, 10$ mmol) with TFA $(4.2 \mathrm{~g}, 20 \mathrm{mmol})$ gave, after distillation [bp $\left.145-150^{\circ} \mathrm{C}(0.7 \mathrm{~mm})\right], 7 e$ in $87 \%$ yield in an impure state. This fraction containing compound $7 \mathrm{e}(1.0 \mathrm{~g}, 3.2 \mathrm{mmol})$ was heated in $15 \mathrm{~mL}$ of toluene in the presence of $2 \mathrm{~mL}$ of trifluoroacetic acid for 3 days. The reaction mixture was washed with sodium bicarbonate solution and then dried $\left(\mathrm{MgSO}_{4}\right)$. Column chromatography [alumina $(\mathrm{V})$, petroleum ether $\left(\mathrm{bp} 60-80^{\circ} \mathrm{C}\right)$ with $5 \%$ $\mathrm{CHCl}_{3}$ ] gave $8 \mathrm{e}(30 \%$ yield) as an oil in an impure state because of decomposition. Compound se could not be crystallized from organic solvents.

7e: ${ }^{1} \mathrm{H}$ NMR $\delta 7.6-7.1(\mathrm{~m}, 4 \mathrm{H}, \mathrm{Ar} \mathrm{H}), 3.6-3.2\left(\mathrm{~m}, 4 \mathrm{H}, \mathrm{NCH}_{2}\right)$, 2.7-2.4 (m, $\left.2 \mathrm{H}, \mathrm{ArCH}_{2}\right), 2.3-1.7\left(\mathrm{~m}, 8 \mathrm{H}, \mathrm{CH}_{2}\right)$; mass spectrum, $m / e 309.135\left(\mathrm{M}^{+}\right.$; calcd for $\left.\mathrm{C}_{17} \mathrm{H}_{18} \mathrm{~F}_{3} \mathrm{NO} 309.134\right)$.

8e: ${ }^{1} \mathrm{H}$ NMR $\delta 7.55-7.0(\mathrm{~m}, 4 \mathrm{H}, \mathrm{Ar} \mathrm{H}) 5.1-4.4(\mathrm{~m}, 2 \mathrm{H}$, NCHO and $\left.\mathrm{F}_{3} \mathrm{CCH}\right), 3.5-1.5\left(\mathrm{~m}, 12 \mathrm{H}, \mathrm{CH}_{2}\right) ;{ }^{13} \mathrm{C} \mathrm{NMR} \delta 124.5(\mathrm{q}, J=$ $\left.283 \mathrm{~Hz}, \mathrm{CF}_{3}\right), 87.6(\mathrm{~d}, \mathrm{NCHO}), 75.2(\mathrm{dq}, J=30 \mathrm{~Hz})$ and $71.8(\mathrm{dq}$, $J=29 \mathrm{~Hz},\left(\mathrm{~F}_{3} \mathrm{CCH}\right), 50.2$ and $49.3\left(\mathrm{t}, \mathrm{NCH}_{2}\right)$; mass spectrum, $m / e 309.133\left(\mathrm{M}^{+}\right.$; calcd for $\left.\mathrm{C}_{17} \mathrm{H}_{18} \mathrm{~F}_{3} \mathrm{NO} 309.134\right)$.

Crystallographic Data and X-ray Structure Analysis of 3. Crystals of 3 have triclinic symmetry, space group $P \overline{1} ; a=$ $13.889(2), b=10.462(1), c=6.801$ (1) $\AA ; \alpha=73.77$ (1) $\beta=75.10$ (1), and $\gamma=73.42(1)^{\circ} ; Z=2 ; d_{\mathrm{c}}=1.34 \mathrm{~g} \mathrm{~cm}^{-3}$. X-ray diffraction intensities were measured with a Philips PW 1100 single-crystal diffractometer [ $\mathrm{Cu} \mathrm{K} \alpha$ radiation, $\lambda=1.5418 \AA$, graphite monochromator, $\theta-2 \theta$ scan mode, $3^{\circ}<\theta<65^{\circ}$, scan speed $(\theta) 0.1^{\circ} / \mathrm{s}$,

(13) Hellberg, L. H.; Milligan, R. J.; Wilke, R. N. J. Chem. Soc. C 1970, 
scan width (deg) $3.3+1.0 \mathrm{tg} \theta]$. The total number of reflections measured was 3315 , of which 2648 had an intensity greater than the standard deviation estimated from counting statistics. The solution and refinement of the crystal structure are based on the latter reflections. The structure was solved by direct methods ${ }^{14}$ and refined by full-matrix least squares ${ }^{15}$ to a final $R$ factor of $5.5 \%$. All hydrogen atoms were found from Fourier difference syntheses. The number of parameters refined in the last cycles was 316 (scale factor, extinction parameter, positional parameters of all atoms, anisotropic thermal parameters for non-hydrogen atoms, isotropic thermal parameters for hydrogen atoms). The figure was produced by ORTEP. ${ }^{16}$

Acknowledgment. We are grateful for the financial support of this work by the "Koningin Wilhelmina Fonds".

Registry No. 1, 67395-20-4; 3, 82281-38-7; 4, 7182-08-3; 5, 82281-39-8; 6a, 31401-28-2; 6b, 31554-37-7; 6c, 7007-34-3; 6d 31401-27-1; 6e, 25579-44-6; 7a, 82281-40-1; 7b, 82281-41-2; 7e, 82281-42-3; 8c, 82281-43-4; 8d (isomer 1), 82281-44-5; 8d (isomer 2), 82281-45-6; 8e (isomer 1), 82281-46-7; 8e (isomer 2), 82281-47-8.

Supplementary Material Available: Tables of atomic coordinates, thermal parameters, bond distances, and bond angles (6 pages). Ordering information is given on any current masthead page.

(14) Germain, G.; Main, P.; Woolfson, M. M. Acta Crystallogr., Sect. $B$ 1970, B26, 274. Main, P. In "Computing in Crystallography"; Schenk, H., Ed.; Delft University Press: Delft, 1978, p 93.

(15) Busing, W. R.; Martin, K. O.; Levy, H. A. “ORFLs”, Oak Ridge National Laboratory, Report ORNL-TM-305, 1962.

(16) Johnson, C. K. “ORTEP”, Oak Ridge National Laboratory, Report ORNL-3794, 1965

\section{Cope and 1,3-Allylic Rearrangements and Ring Closure of the 1,5-Hexadiene Radical Cation Prior to Decomposition in the Gas Phase}

$$
\text { P. Wolkoff* }
$$

Chemical Laboratory II, The H. C. Orsted Institute, University of Copenhagen, $D K-2100$ Copenhagen $\oslash$, Denmark

\section{J. L. Holmes}

Chemistry Department, University of Ottawa, Ottawa, Ontario, Canada KIN $9 B 4$

\section{Received April 6, 1982}

The chemistry of neutral 1,5-hexadiene (1) has been studied extensively. It undergoes the well-known (degenerate) Cope rearrangement under thermal conditions. ${ }^{1}$ Facile transformations occur upon irradiation, and depending on the photochemical conditions allylcyclopropane $^{2}$ and bicyclo[2.1.1]- and [2.2.0] hexane ${ }^{3}$ may be formed. Isotopic separation of deuterated 1 in favor of deuterium situated in the external vinyl sites has been demonstrated with infrared laser; ${ }^{4}$ deuterium in the allylic positions, however, is favored under thermal conditions. ${ }^{5}$

In contrast, recent electron impact studies indicate a chemical inertness of the radical cation of $1\left(1^{+}.\right)$. It was

(1) J. J. Gajewski, Acc. Chem. Res., 13, 142 (1980), and references therein.

(2) T. D. R. Manning and P. J. Kropp, J. Am. Chem. Soc., 103, 889 (1981).

(3) (a) R. Srinivasan and K. Hill Carlough, $J$. Am. Chem. Soc, 89, 4932 (1967). (b) R. Srinivasan and F. J. Sonntag, ibid., 89, 407 (1967).

(4) J. Glatt and A. Yogev, J. Am. Chem. Soc., 98, 7087 (1976).

(5) K. Humski, R. Malojcic, S. Borcic, and D. Sunko, J. Am. Chem. Soc., 92, $6534(1970)$.

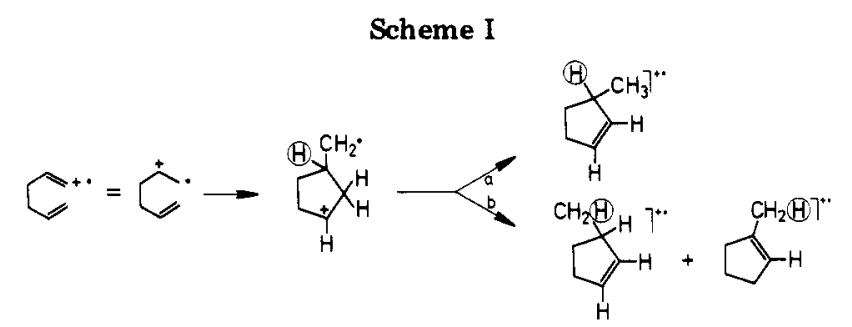

shown by photodissociation spectroscopy that $1^{+}$. remains as an unconjugated diene at low internal energies. ${ }^{6}$ Comparison of the heat of formation ${ }^{7}$ of $\mathrm{C}_{5} \mathrm{H}_{7}{ }^{+}$ions formed by $\mathrm{CH}_{3}$. loss from isomeric $\mathrm{C}_{6} \mathrm{H}_{10}$ radical cations (ions of $\mathrm{m} / z 67$ give rise to base peak in the normal mass spectra of $\mathrm{C}_{6} \mathrm{H}_{10}$ isomers $\left.{ }^{8}\right)$ and the kinetic energy release $(T)^{9}$ associated therewith showed that $1^{+}$. among its linear isomers forms the cyclopentenyl cation with the lowest excess energy and smallest $T$ value. ${ }^{10}$ This result is in accord with the photodissociation results insofar as $\mathbf{1}^{+}$. cannot isomerize to another linear diene prior to decomposition. The collisional activation mass spectra ${ }^{11}$ of $\mathrm{C}_{6} \mathrm{H}_{10}$ isomers confirmed that nondecomposing $1^{+}$. has no or only little resemblance with the radical cations of 1,3-, 1,4-, and 2,4hexadiene, cyclohexene, and 1-methylcyclopentene. ${ }^{12}$

In light of the apparent retention of structure of $1^{+} \cdot$, this work is concerned with how the cyclopentenyl cation is formed therefrom.

It is necessary to consider which isomeric $\mathrm{C}_{6} \mathrm{H}_{10}{ }^{+}$. ions have heats of formation lying below the energy required for fragmentation of $1^{+}$. by $\mathrm{CH}_{3}$. loss and which can display similar kinetic energy release characteristics. From our previous studies, ${ }^{10,13}$ these can be reduced to cyclohexene, 2-methyl-1,4-pentadiene, and methylcyclopentene (and methylenecyclopentane); see Table I.

Isomerization of $1^{+}$. to the cyclohexene radical cation is not likely to occur, because it would involve the formation of bicyclo[2.2.0] hexane $^{+}$. in the first step, a process having an energy barrier of $16 \mathrm{kcal} \mathrm{mol}^{-1}$ (see Table I). Loss of ethylene is an abundant process of the cyclohexene radical cation (RDA elimination), ${ }^{8}$ while it is nearly absent in the normal mass spectrum and in the metastable time frame of $1^{+}$, thus further disfavoring an isomerization. ${ }^{14}$

Ionized 2-methyl-1,4-pentadiene also cannot be involved in the behavior of $1^{+}$, because the kinetic energy release for the random statistical losses of the deuterium-labeled methyl radicals from 2-methyl-1,4-pentadiene-1,1- $d_{2}^{+} \cdot$ was twice as large as that observed for the unlabeled compound, ${ }^{13}$ while this is not the case with labeled 1,5 -hexadienes (see also note 23).

(6) R. C. Benz, R. C. Dunbar, and P. C. Claspy, J. Am. Chem. Soc., 103, 1799 (1981).

(7) K. Levsen, "Fundamental Aspects of Organic Mass Spectrometry", Verlag Chemie, Weinheim, 1978, Chapter 4).

(8) A. Cornu and R. Massot, "Compilation of Mass Spectral Data", 2nd ed., Vol. I, Heyden, London, 1975.

(9) J. L. Holmes and J. K. Terlouw, Org. Mass Spectrom., 15, 383 (1980); R. G. Cooks, J. H. Beynon, R. M. Caprioli, and G. R. Lester "Metastable Ions", Elsevier, Amsterdam, 1973.

(10) P. Wolkoff, J. L. Holmes, and F. P. Lossing, Can. J. Chem., 58, 251 (1980).

(11) K. Levsen and H. Schwarz, Angew. Chem., Int. Ed. Engl., 15, 509 (1976).

(12) The CA mass spectra were measured on a ZAB-2F mass spectrometer using $\mathrm{He}$ as a collision gas. The spectra were averaged and corrected for unimolecular decomposition.

(13) P. Wolkoff and J. L. Holmes, Can. J. Chem., 57, 348 (1979)

(14) Comparison of the data obtained for losses of deuterated methyl from cyclohexene-3,3,6,6-d $d_{15}^{15}$ with those from 1,5-hexadiene-1,1,6,6-d $(2$ see Table II) clearly show a dissimilarity in disfavor of an isomerization; in particular note the absence of $\mathrm{CD}_{3}$. loss from the former.

(15) P. J. Derrick, A. M. Falick, and A. L. Burlingame, J. Am. Chem. Soc., 94, 6794 (1972) 